\title{
Komisyoncuların Hal Kayıt Sisteminin etkinliği hakkındaki görüşleri: İzmir ili yaş sebze ve meyve toptancı hali örneği
}

\author{
Brokers' views on the effectiveness of the wholesale market registration system: A \\ case study of fresh fruit and vegetable wholesale market in İzmir province
}

\author{
Hakan ADANACIOĞLU@, Filiz KINIKLIĐ, Gizem ÖZER ${ }^{\circledR}$, Cemile YILMAZ® \\ Ege Üniversitesi, Ziraat Fakültesi, Tarım Ekonomisi Bölümü, Bornova/İzmir \\ Sorumlu yazar (Corresponding author): H. Adanacı̆̆glu, e-posta (e-mail): hakan.adanacioglu@ege.edu.tr \\ Yazar(lar) e-posta (Author e-mail): filiz.kinikli@ege.edu.tr,gzm.773@gmail.com, cemileylmz2@outlook.com
}

\section{MAKALE BİLGİSİ}

Alınış tarihi 09 Haziran 2019

Düzeltilme tarihi 22 Temmuz 2019

Kabul tarihi 26 Temmuz 2019

\section{Anahtar Kelimeler:}

Hal Kayıt Sistemi

Toptancı halleri

Komisyoncular

Sebze ve meyve

\begin{abstract}
ÖZ
Türkiye'de 11.03.2010 tarih ve 5957 sayılı kanun ile sebze ve meyve sektöründeki kayıt dışıllı̆ önlemek amacıyla Hal Kayıt Sistemi kurulmuştur. Hal Kayıt Sistemi, Ticaret Bakanlığı'nın kontrolünde çalışan internet tabanlı bir kayıt merkezidir. Bu çalışmada Hal Kayıt Sisteminin kayıt dıșılığı önlemek adına ișlevsel olarak etkin çalıșıp çalıșmadığı sorusuna yanıt aranmıștır. Bu kapsamda, İzmir Büyükşehir Belediyesi Kaynaklar Yaş Sebze ve Meyve Toptancı Halindeki 30 komisyoncu ile anket yapılmıștır. Komisyoncuların Hal Kayıt Sisteminin kayıt dışılığı önlemedeki etkisi ve Hal Kayıt Sistemi hakkında gördükleri en önemli sorunlar calıșma kapsamında incelenen başlıca konulardır. Komisyoncuların \%36.7'si Hal Kayıt Sisteminin kayıt dışılığı önlemede etkisinin olmadığını düşünürken, \%30’u da bu konuda kararsız kaldıklarını belirtmişlerdir. Komisyoncuların görüslerine göre Hal Kayıt Sisteminde görülen en önemli sorun, üretilen ürünlerin önemli bir kısmının sisteme kayıt olmadan pazara arz edilmesidir. Bunun da en önemli nedeni olarak Hal Kayıt Sistemi hakkında üreticilerin bilgi eksikliği gösterilmektedir. Tarımsal üreticiler, Hal Kayıt Sistemine bildirim yapanlar içinde önemli paya sahiptir. Bu nedenle sistemdeki kayıt dișılı̆̆ önlemek amacıyla özellikle de üreticilere yönelik bilgilendirme ve sistemin nasıl kullanılacağına ilişkin eğitim çalışmaları önem taşımaktadır. Hal Kayıt Sisteminin etkin çalışması için sistemde yer alan tüm aktörlerin denetlenmesini sağlayacak şekilde sistemin yeniden yapılandırılmas gerekmektedir. Ayrıca, bazı teşvik mekanizmaları ile sisteme kayıt olmak cazip hale getirilmelidir.
\end{abstract}

\section{ARTICLE INFO}

Received 09 June 2019

Received in revised form 22 July 2019

Accepted 26 July 2019

\section{Keywords:}

Wholesale market registration system

Wholesale markets

Brokers

Vegetable and fruits

\begin{abstract}
The wholesale market registration system was established by Law No. 5957/11.03.2010 in order to prevent unregistered transactions in the fruit and vegetable sector in Turkey. The wholesale market registration system is an internet based registration center that operates under the control of the Republic of Turkey, Ministry of Trade. In this study, the answer to the question of whether the wholesale market registration system works effectively in preventing unregistered transactions was sought. In this context, a survey was conducted with 30 brokers in Izmir Metropolitan Municipality's Kaynaklar wholesale market for fresh fruit and vegetables. The most important problems about the wholesale market registration system as well as the effect of the registration system on preventing unregistered transactions are the main issues examined within the scope of the study. While $36.7 \%$ of the brokers thought that the wholesale market registration system had no effect in preventing unregistered transactions, $30 \%$ stated that they were undecided about this issue. According to the opinions of the brokers, the most important problem in the wholesale market registration system was the fact that a significant portion of the products produced were placed on the market without registration. The brokers emphasized that the most important reason for this was the lack of knowledge of producers about the wholesale market registration system. Agricultural producers have an important share among those reporting to the wholesale market registration system. For this reason, it is important to inform producers and to train producers about how to use the system in order to prevent unregistered transactions in the system. The system needs to be restructured to ensure that all the actors in the system are audited for the effective operation of the wholesale market registration system. In addition, registration with the system should be made attractive with some incentive mechanisms.
\end{abstract}




\section{Giriş}

Toptancı halleri, yaş sebze ve meyvenin toptan alımsatımının yapıldığı, fiyatın arz ve talebe göre oluştuğu toptan pazarlardır (Yılmaz ve Y1lmaz 2002). 11.03.2010 tarihli ve 5957 sayıl1 "Sebze ve Meyveler ile Yeterli Arz ve Talep Derinliği Bulunan Diğer Malların Ticaretinin Düzenlenmesi Hakkındaki Kanunda" ise toptancı halleri, "asgarî koşulları taşıyan projeler çerçevesinde belediyeler ile gerçek veya tüzel kişiler tarafından kurulan, malların ayrı ayrı yahut birlikte toptan alım ve satımı ile kaydının yapıldı ğı yerler" olarak tanımlanmaktadır (Resmi Gazete 2010).

Türkiye, farklı iklim özelliklerine sahip olması nedeniyle çok farklı meyve ve sebze üretimine imkan vermektedir. Meyve ve sebze pazarlamasında çeşitli konumlarda çok sayıda aracı kuruluşlar faaliyet göstermektedir. Türkiye'de yaş meyve ve sebze pazarlamasında en önemli aracı kuruluşu ise Yaş Sebze ve Meyve Toptancı Halleridir (Aydın Can ve Engindeniz 2018). Türkiye'de taze sebze ve meyve pazarlaması alanında toptancı hallerinin önemli bir yeri vardır (Sayılı ve Civelek 2012).

Üretilen taze meyve ve sebzelerin belediye sinırları içerisinde uygun olan yerlerde satışının yapılabilmesi için mutlaka toptanc1 hallerinden satın alınmış olduğunun belgelendirilmesi gereklidir. $\mathrm{Bu}$ durum kayıt dışılığın önüne geçebilmek için bir yasal zorunluluktur. Bununla birlikte işlenmiş sebze ve meyvelerin perakende satışlarının yapılabilmesi için de toptancı hallerine girişin yapılmış olması gerekmektedir (Emeksiz ve ark. 2014).

Türkiye'de Toptancı Halleri ile ilgili 1960'lı yıllardan beri birçok yasa ve düzenleme çıkartılmıştır. 1960 yılında yürürlüğe giren 'Toptanc1 Hallerinin Sureti İdaresi Hakkında Kanun" kapsamında toptanc1 halleri belediyelerin sorumluluğunda yönetilmekteydi (Demirbaş 2001). Daha sonra 1995 yılında yürürlüğe giren 'Taze Sebze ve Meyve Ticaretinin Düzenlenmesi ve Toptancı Halleri Hakkında Kanun Hükmünde Kararname' ile haller yasası tekrar değişikliğe uğramıştır. 1998 yılında söz konusu 552 sayılı KHK'de bazı değişiklikler yapılarak tekrar yasalaşması sağlanmıştır (Giray 1998). Yapılan değişiklikten yaklaşık 10 yıl sonra 'Taze Sebze ve Meyve Ticaretinin Düzenlenmesi ve Toptancı Halleri Hakkında Kanun Hükmünde Kararnamenin Bazı Maddelerinin Değiştirilerek Kabulüne İlişkin Kanun' çıarılarak 552 sayılı haller kanunu tekrar değişmiştir. Genel olarak incelendiğinde bu yasalarda, ürün alım-satım işlemlerinin hallerdeki nasıl olacağı, bunları kimlerin yürüteceği, haldeki ürünlerin kalitesi, depolanmas1, standardizasyonu, ürün satış fiyatının belirlenmesi, haldeki pazarlama işlemlerinde karşılaşılan sorunların nasıl çözüleceği gibi konular ele alınmıştır (Sayılı ve Civelek 2012). Ayrıca, 552 sayılı KHK'de; yaş sebze ve meyvelerin öncelikle hallerde toplanması; serbest rekabet koşulları altında en uygun fiyat oluşumunun sağlanması ve denetimin geniş ölçüde belediyeler eliyle yürütülmesi esasları üzerinde durulmuştur (Sayın ve Mencet 2007).

Toptancı halleri ile ilgili yapılan son düzenleme ise 26.03.2010 tarihli ve 27533 say1l1 Resmi Gazete 'de yayımlanan "5957 sayıl1 Sebze ve Meyveler İle Yeterli Arz ve Talep Derinliği Bulunan Diğer Malların Ticaretinin Düzenlenmesi Hakkında Kanun"dur (Resmi Gazete 2010). Bu kanun 07.07.2012 tarihli ve 28346 sayılı Resmî Gazetede yayınlanan "Sebze ve Meyve Ticareti ve Toptancı Halleri Hakkında Yönetmelik" ile yürürlüğe girmiştir. Bu yönetmeliğin çıkarılış amacı, "sebze ve meyve ticaretinin kaliteli, standartlara ve gıda güvenilirliğine uygun olarak serbest rekabet şartları içinde yapılmasını sağlamak, toptancı hallerini modern bir yapıya kavuşturmak, toptancı hali içinde veya dişında işlem gören sebze ve meyvelere ilişkin bilgileri elektronik ortamda tutmak, izlemek ve duyurmak, meslek mensupları ile diğer ilgilileri kayıt altına almak, bunlara yönelik veri tabanı oluşturmak, toptancı halleri arasında ortak bilgi paylaşımını ve iletişimi temin etmek, üretici ve tüketicilerin hak ve menfaatlerini korumak ve meslek mensuplarının faaliyetlerini düzenlemek" olarak belirtilmektedir (Resmi Gazete 2012). 11.03.2010 tarihli ve 5957 sayıli Sebze ve Meyveler ile Yeterli Arz ve Talep Derinliği Bulunan Diğer Malların Ticaretinin Düzenlenmesi Hakkında Kanunun 3, 5, 9, 12, 15 ve 16. maddelerine dayanılarak hazırlanan bu yönetmelik ile kayıtlı olmayan aracıların mümkün olduğu kadar ortadan kaldırılması, üreticilerin toptancı hallerine erişim maliyetlerinin azaltılması ve çiftçilerin ürünlerini doğrudan perakendecilere satabilmeleri hedeflenmiştir (Aysoy ve ark. 2015).

5957 sayıl Sebze ve Meyveler ile Yeterli Arz ve Talep Derinliği Bulunan Diğer Malların Ticaretinin Düzenlenmesi Hakkında Kanunundaki şüphesiz ki en önemli düzenleme Hal Kayı1 Sistemidir. 07.07.2012 tarihinde 28346 say1l resmi gazetede yayınlanan "Sebze ve Meyve Ticareti ve Toptanc1 Halleri Hakkında Yönetmelik"te Hal Kayıt Sistemi, "bakanlık bünyesinde elektronik ortamda kurulan ve internet tabanlı çalışan merkezi" ifade etmektir. Elektronik ortamda kurulan ve internet tabanlı çalışan bu sistem ile sebze ve meyve ticaretinin kaliteli, standartlara ve gida güvenilirliğine uygun olarak serbest rekabet şartları içinde yapılmasının sağlanması, toptancı hali içinde veya dışında işlem gören sebze ve meyvelere ilişkin bilgilerin elektronik ortamda tutulması, izlenmesi ve duyurulması, meslek mensupları ile diğer ilgililerin kayıt altına alınması, bunlara yönelik veri tabam oluşturulması ve toptancı halleri arasında ortak bilgi paylaşımı ve iletişiminin sağlanması amaçlanmıştır (Resmi Gazete 2010; Adanacioğlu ve Yercan 2012). Hal Kayıt Sisteminin etkin bir şekilde çalışması ile sektördeki kayıt dışı işlemlerin önemli oranda sona ereceği ve sektörün kontrol altında tutulabileceği öngörülmüştür (Adanacıŏlu ve Yercan 2012). Bununla birlikte, bugüne kadar Hal Kayıt Sisteminin kayıt dışılı̆̆ı önlemek adına işlevsel olarak etkin çalışıp çalışmadığı konusunda somut bilgi bir bilgiye ulaşılamamıştır.

Hal Kayıt Sisteminin şüphesiz ki en önemli kullanıcıları toptancı hallerinde yer alan komisyonculardır. Nitekim, üreticiler satış bildirimlerini genelde toptancı hallerindeki çalıştıkları komisyoncular kanalı ile yetki vererek yapmaktadır. 5957 sayılı kanunda komisyoncular, malların toptan satış1 amacıyla kendi adına ve başkası hesabına komisyon esası üzerinden çalışan meslek mensupları olarak tanımlanmaktadır (Resmi Gazete 2010). Bu tanımlamadan da anlaşılacağı üzere komisyoncular, üreticiler yanında tüccarlar, perakendeciler ve ihracatçıların da dahil olduğu çok sayıda pazarlama kanal üyesi ile çalışan önemli bir aktör konumundadır. $\mathrm{Bu}$ çerçevede komisyoncular, Hal Kayıt Sisteminin uygulamaya geçtiği günden bugüne kadarki dönemde sistemin işleyişi ile ilgili sorulara en net yanıt alınabilecek aktörler olarak görülmektedir.

Literatürde yapılan çalışmalar incelendiğinde; toptanc1 halleri ile ilgili yapılan araştırmalarda genellikle toptancı hallerinin işleyiş biçimleri ve toptancı hallerinin sorunları üzerinde durulmuş, hal yasalarını karşılaştıran ve yasal düzenlemeleri inceleyen çalışmalara rastlanmıştır (Y1lmaz ve Y1lmaz 2002; Hadimli ve Bulut 2004; Canik ve Alparslan 2010; Gözener ve Sayılı 2011; Adanacıŏglu ve Yercan 2012; Coşkun 2014; Coşkun ve Tunalığlu 2015; Ölmez ve Demirörs 2015; 
Apal1 ve Bozcu 2018; Aydın Can ve Engindeniz 2018). Bununla birlikte, yapılan incelemelerde 5957 sayılı kanunun en önemli düzenlemesi olan ve kayıt dışılığı önlemek amacıyla kurulan Hal Kayıt Sisteminin işlevsel olarak etkin çalışıp çalışmadı ğı konusunda gerçekleştirilen bir araştırma ile karşılaşılmamıştır. $\mathrm{Bu}$ çalışma ile söz konusu boşluğun doldurulması amaçlanmıştır. Bu kapsamda, İzmir Büyükşehir Belediyesi Kaynaklar Yaş Sebze ve Meyve Toptancı Halindeki komisyoncular örnek olay olarak incelenmiştir. Komisyoncuların Hal Kayıt Sisteminin kayıt dışılığ önlemedeki etkisi ve Hal Kayıt Sistemi hakkında gördükleri en önemli sorunlar çalışma kapsamında incelenen başlıca konulardir.

\section{Materyal ve Yöntem}

$\mathrm{Bu}$ çalışmanın ana materyalini, İzmir Büyükşehir Belediyesinin Kaynaklar Yaş Meyve ve Sebze Halindeki komisyoncular ile yüz yüze yapilan anketlerden elde edilen veriler oluşturmaktadır. Önceden yayınlanmış tezler, araştırmalar, makaleler, bildiriler ve proje raporları ise çalışmanın ikincil veri kaynaklarını oluşturmaktadır.

Araştırmada İzmir Büyükşsehir Belediyesi Kaynaklar Yaş Meyve ve Sebze Halinde faaliyet gösteren ve görüşmeyi kabul eden 30 komisyoncu ile anket yapılmıştır. Tarım ekonomisi araştırmalarında en az 30 birimlik bir örneğin normal dağılım gösterdiği kabul edilmektedir (Çiçek ve Erkan 1996). Anket yoluyla toplanan veriler, gerekli kodlamalar ve kontroller yapıldıktan sonra Excel ve SPSS paket programına girilmiştir. Elde edilen veriler temel tanımlayıcı istatistikler kullanılarak çizelgeler halinde özetlenmiştir. Komisyoncuların Hal Kayıt Sistemine ilişkin sorunları ise Best-Worst (En iyi-En kötü) analizi ile ortaya konulmuştur.

\section{Bulgular}

\subsection{Komisyoncular ile ilgili genel bulgular}

Araştırma kapsamında İzmir Büyükşehir Belediyesi Kaynaklar Yaş Meyve ve Sebze Halinde faaliyet gösteren 30 komisyoncu ile görüşülmüş ve komisyoncuların yaş ortalamasının 41.87 olduğu tespit edilmiştir. Komisyoncuların \%50'si ortaokul mezunu iken \%26.7'si lise, \%23.3'ü ise ilkokul mezunudur. Hane halk1 büyüklüğü incelendiğinde ise komisyoncuların ailedeki birey sayısının (6.68) Türkiye (3.48) ve İzmir ili (3.04) ortalamasının oldukça üzerinde olduğu dikkat çekmektedir (İzmir Valiliği 2017). Bunun nedeni, komisyoncuların genellikle "geniş aile" olarak nitelendirilen anne, baba, çocuk, babaanne, dede vb. bireylerin hep bir arada yaşadığ 1 geleneksel bir aile tipine sahip olmalarından kaynaklanmaktadır. Yaklaşı 7 kişilik bir aileye sahip olan komisyoncuların ailesinden 3 kişinin aynı işle uğraşıyor olduğu görülmüştür. $\mathrm{Bu}$ durum komisyoncuların küçük yaşta aile yanında işe başladıklarının bir göstergesi olarak değerlendirilebilir. Komisyoncuların eğitim durumu, yaş ve komisyonculuk deneyimi incelendiğinde de bu durumu kanıtlar nitelikte sonuçlara varılmıştır (Çizelge 1).

Görüşülen komisyoncuların sosyal güvence durumu incelendiğinde ise \%93.3'ünün sosyal güvencesinin Bağkur olduğu tespit edilmiştir. Kocaeli toptanc1 halinde görev yapan komisyoncular ile yapılan benzer bir çalışmada ise komisyoncuların \%55'inin sosyal güvencesi Bağkur iken \%30'unun sosyal güvencesinin SSK olduğu tespit edilmiştir (Aydin Can ve Engindeniz 2018).
Araştırma kapsamında görüşülen komisyoncuların yaklaşık 20 yıldır sebze-meyve ticareti ile uğraştığı belirlenmiştir. Aydın ilinde komisyoncular ile yapılan benzer bir çalışmada komisyoncuların \%37.2'sinin 11-20 yıldır bu mesleği yaptıkları tespit edilmiştir (Coşkun ve Tunalıŏlu 2015). Antalya ilinde 2002 yılında yapılan bir diğer çalışmada da komisyoncuların ortalama deneyim süresi 18.3 yıl olarak bulunmuştur (Y1lmaz ve Yilmaz 2002).

Komisyoncuların yanlarında yaklaşık 7 kişi çalıştırdığı ve \%93.1'inin yıllık cirolarının 200.001 TL ve üstü olduğu saptanmıştır. Görüşülen komisyoncuların \%96.7'sinin komisyonculuk dışında bir gelirinin olmadığı, \%86.7'sinin ise daha önce pazarcılık yaptıkları belirlenmiştir (Çizelge 1).

Çizelge 1. Komisyoncuların genel özellikleri.

Table 1. General features of brokers.

\begin{tabular}{|c|c|c|}
\hline Genel Özellikler & Seçenekler & Say1/Yüzde \\
\hline Yaş (y1l) & & 41.87 \\
\hline \multirow[t]{3}{*}{$\overline{\text { Eğitim Düzeyi (\%) }}$} & İlkokul & 23.3 \\
\hline & Ortaokul & 50.0 \\
\hline & Lise & 26.7 \\
\hline Ailedeki birey sayısı (kişi) & & 6.68 \\
\hline $\begin{array}{l}\text { Ailede komisyonculuk yapan } \\
\text { kiși sayısı }\end{array}$ & & 3.03 \\
\hline \multirow[t]{6}{*}{ Sosyal Güvence Durumu } & Yok & 3.3 \\
\hline & SSK & 3.3 \\
\hline & Bağkur & 93.3 \\
\hline & Emekli sandı̆̆ & 0.0 \\
\hline & Yeşilkart & 0.0 \\
\hline & Özel sigorta & 0.0 \\
\hline $\begin{array}{l}\text { Hal içinde sebze-meyve } \\
\text { ticaretiyle uğraşma süresi (yıl) }\end{array}$ & & 19.43 \\
\hline $\begin{array}{l}\text { Komisyoncunun yanında } \\
\text { çalışan eleman sayısı }\end{array}$ & & 6.87 \\
\hline \multirow[t]{4}{*}{ Yillık Ciro (TL) (\%) } & 100.000 TL'den az & 0.0 \\
\hline & $100001-150.000$ & 0.0 \\
\hline & $150.001-200.000$ & 6.9 \\
\hline & 200.001 ve üstü & 93.1 \\
\hline \multirow{4}{*}{$\begin{array}{l}\text { Komisyonculuktan önce } \\
\text { yapılan iş (\%) }\end{array}$} & Pazarcilık & 86.7 \\
\hline & Tüccar & 3.3 \\
\hline & Üretici & 6.7 \\
\hline & Nakliyecilik & 3.3 \\
\hline \multirow{2}{*}{$\begin{array}{l}\text { Bilgisayar kullanmayı bilme } \\
\text { durumu }(\%)\end{array}$} & Evet & 93.3 \\
\hline & Hayır & 6.7 \\
\hline \multirow[t]{2}{*}{ Komisyonculuk diş1 gelir (\%) } & Var & 3.3 \\
\hline & Yok & 96.7 \\
\hline
\end{tabular}

3.2. Komisyoncular tarafindan alım-satımı yapılan ürünler ve ticareti

Araştırma kapsamında görüşülen komisyoncuların ürünlerini genellikle üreticilerden tedarik ettikleri belirlenmiştir. Aydın ilinde komisyoncular ile yapılan benzer bir çalışmada da, komisyoncuların \%89.5'inin, Antalya ilinde yapılan bir çalışmada ise \%80.5'inin ürünleri üreticilerden tedarik ettikleri tespit edilmiştir (Coşkun 2014; Yilmaz ve Yilmaz 2002). Komisyoncuların en fazla sattığı ürünler ve sattıkları yerler incelenmiştir. Buna göre; komisyoncular soğanın \%46.25'ini pazarcılara, \%39'unu marketlere satmaktadırlar. Patatesin ise genellikle pazarcılara, marketlere ve yemekhane- restoran gibi toplu tüketim yerlerine satıldığı saptanmıştır (Çizelge 2). 
Çizelge 2. Komisyoncuların ürün satış yerleri**

Table 2. Marketing channels where brokers sell products.

\begin{tabular}{|c|c|c|c|c|c|}
\hline Ürün Adı* & Market(\%) & $\operatorname{Manav}(\%)$ & Pazarcı(\%) & $\begin{array}{l}\text { Okul, hastane, askeri birlik, fabrika } \\
\text { yemekhaneleri, otel, restoran }(\%)\end{array}$ & İhracatçı $(\%)$ \\
\hline Soğan & 39.00 & 23.75 & 46.25 & 25.00 & - \\
\hline Patates & 39.64 & 27.22 & 44.17 & 42.50 & - \\
\hline Mandalina & 48.75 & 33.75 & 51.11 & 32.50 & 87.50 \\
\hline Şeftali & 40.00 & 33.18 & 44.23 & 35.00 & 55.00 \\
\hline Elma & 42.78 & 32.27 & 40.42 & 45.83 & - \\
\hline Armut & 36.25 & 39.00 & 45.00 & 22.50 & - \\
\hline Domates & 31.67 & 22.50 & 33.75 & 31.43 & - \\
\hline
\end{tabular}

*Birden fazla cevap verildiği için toplam \%100’ü aşmaktadır.

Komisyoncu; üreticilerin ve tüccarların getirdiği malları kendi komisyonunu kesmek koşuluyla onları çıkarları doğrultusunda başka tüccarlara, pazarcılara, marketlere vb. satmakla yükümlüdür. Komisyoncunun bu satıștan çıkarı toptancı hal kanunlarına göre en fazla $\% 8$ oranında olmak zorundadır. Komisyoncu, yaptığı satışlara karşılık olarak fatura kesmek ve kestiği faturaları günlük bordro halinde hal müdürlüğüne teslim etmekle yükümlüdür. İlave olarak, satış tutarından $\% 8$ komisyon, \%2 rüsum, \%2 stopaj kesmektedir (Y1lmaz ve Y1lmaz 2002). Komisyoncular, ürünleri genellikle üreticilerden temin etmektedirler. Üreticilerin komisyonculara ürününü satarken bazı kesintiler olmaktadır. Komisyoncular, bu kesintilerin \%8.6'sinın komisyon, \%3.7'sinin ise vergi olduğunu belirtmişlerdir (Çizelge 3).

Hal rüsumu; malları satın alanlarca toptan satış bedeli üzerinden toptancı hali bulunan belediye veya işletmelere ödenen meblağdır. Hal kanununda yapılan düzenlemeler ile kayıt dişı işlemleri azaltmak hedeflenmiştir. Bu çerçevede, "malları satın alanlarca toptan satış bedeli üzerinden ödenen meblağ" olarak tanımlanan hal rüsumu azaltılmıştır. Buna göre; toptanc1 halinde satılan mallardan \%1, toptancı hali dışında satılan mallardan $\% 2$ oranında hal rüsumu tahsil edilmektedir. Ayrıca iyi tarım uygulamaları kapsamında sertifikalandırılan ürünlerden ve organik tarım faaliyetleri esaslarına uygun olarak üretilen sertifikalı ürünlerden hal rüsumu alınmamaktadır (Adanacıŏlu ve Yercan 2012).

Satışta hal rüsumunu kimin ödediği sorulduğunda ise komisyoncuların \%66.7'si kendilerinin ödediklerini söylemişlerdir. Hal rüsumu ödediğini belirten komisyoncuların y1llık ödediği hal rüsumu ise ortalama 41.1 TL'dir (Çizelge 3).

Komisyonculara hal rüsumu oranını ne düzeyde bulduklarına dair soru yöneltildiğinde; \%43.3'ü yüksek bulduğunu belirtmiştir. Aydın ilinde komisyoncular ile yapılan benzer bir çalışmada da komisyoncuların \%55.3'ü kesintilerin yüksek olduğunu düşünmektedir (Coşkun 2014).

\subsection{Komisyoncuların Hal Kayıt Sistemi hakkındaki görüşleri}

Hal kayıt sistemi, daha önceki Hal kanunlarında bulunmayan 5957 sayılı kanunla hayata giren bir yeniliktir. Hal Kayıt Sistemi hale giren ve çıkan bütün tarımsal ürünlerin üretildiği yeri, adını, cinsini gösteren, alıcı ve satıcı bilgilerini de içeren elektronik ortamda kurulan ve internet tabanlı olarak çalışan merkezi bir sistemdir (Adanacıoğlu ve Yercan 2012). Komisyoncuların \%93’ü Hal Kayıt Sisteminin kullanımı hakkında bilgi sahibi olduğunu ifade etmiştir (Çizelge 4).

Komisyonculara üreticilerin Hal Kayit Sistemine bildirim yapıp yapmadıkları sorulmuştur. Komisyoncuların \%40’1
Çizelge 3. Komisyonculardan alınan yasal kesintiler ve yasal kesintiler hakkındaki görüşleri.

Table 3. Legal deductions paid by brokers and their views on these deductions.

\begin{tabular}{llc}
\hline Yöneltilen Sorular & Seçenekler & $\begin{array}{c}\text { Yüzde } \\
(\%)\end{array}$ \\
\hline Üreticilerden ürün alımındaki & Komisyon & 8.6 \\
kesintiler & Vergi & 3.7 \\
\hline Satışta hal rüsumunu Ödeme Durumu & Üretici & 10.0 \\
& Kendim & 66.7 \\
& Üretici ve Kendim & 23.3 \\
\hline Yıllık ödenen hal rüsumu miktarı (TL) & & 41.1 \\
\hline Hal rüsumu oranının düzeyi & Düşük & 20.0 \\
& Orta & 36.7 \\
& Yüksek & 43.3 \\
\hline
\end{tabular}

Çizelge 4. Komisyonculara göre Hal Kayıt Sisteminin üreticiler tarafindan kullanım durumu.

Table 4. The use of wholesale market registration system by producers according to brokers' views.

\begin{tabular}{|c|c|c|}
\hline Yöneltilen Sorular & Seçenekler & $\begin{array}{l}\text { Yüzde } \\
(\%)\end{array}$ \\
\hline \multirow{2}{*}{$\begin{array}{l}\text { Hal Kayıt Sistemini } \\
\text { kullanmayı bilme durumu }\end{array}$} & Evet & 93.3 \\
\hline & Hayır & 6.7 \\
\hline \multirow{5}{*}{$\begin{array}{l}\text { Komisyonculara göre } \\
\text { üreticilerin Hal Kayıt } \\
\text { Sisteme ürünlerinin satışını } \\
\text { bildirme durumu }\end{array}$} & Hiçbiri Bildirmiyor & 13.3 \\
\hline & Çok Azı Bildiriyor & 26.7 \\
\hline & Yarıya Yakını Bildiriyor & 20.0 \\
\hline & Büyük Kısmı Bildiriyor & 40.0 \\
\hline & Hepsi Bildiriyor & 0.0 \\
\hline \multirow{6}{*}{$\begin{array}{l}\text { Komisyoncuların, } \\
\text { üreticilerin Hal Kayıt } \\
\text { Sistemine nasıl bildirim } \\
\text { yaptıkları konusunda } \\
\text { bilgileri }\end{array}$} & Hale doğrudan başvuruyorlar & 36.7 \\
\hline & Çağnı merkezi ile yapıyorlar & - \\
\hline & $\begin{array}{l}\text { İnternet (e-bildirim) ile } \\
\text { yapıyorlar }\end{array}$ & 16.7 \\
\hline & $\begin{array}{l}\text { Akıllı telefon uygulaması ile } \\
\text { yapıyorlar }\end{array}$ & 30.0 \\
\hline & $\begin{array}{l}\text { Ticaret Bakanlığı ticaret il } \\
\text { müdürlüğ̈̈ aracılığıyla } \\
\text { yapıyorlar }\end{array}$ & - \\
\hline & Üretici adına biz yapıyoruz & 16.7 \\
\hline \multirow{4}{*}{$\begin{array}{l}\text { Komisyonculara göre } \\
\text { üreticilerin Hal Kayıt } \\
\text { Sistemine bildirim } \\
\text { yapmaktan kaçınmalarının } \\
\text { nedenleri }\end{array}$} & Uğraşmak istemiyorlar & 10.0 \\
\hline & HKS hakkında bilgileri yok & 26.7 \\
\hline & $\begin{array}{l}\text { Vergi ödemekten } \\
\text { kaçınıyorlar }\end{array}$ & 56.7 \\
\hline & Diğer & 6.7 \\
\hline \multirow{5}{*}{$\begin{array}{l}\text { Komisyonculara göre Hal } \\
\text { Kayıt Sisteminin çalışma } \\
\text { durumu }\end{array}$} & Hiç iyi çalışmıyor & 20.0 \\
\hline & Biraz iyi & 6.7 \\
\hline & Orta (kararsiz) & 6.7 \\
\hline & Oldukça iyi & 63.3 \\
\hline & Kesinlikle çok iyi & 3.3 \\
\hline
\end{tabular}


üreticilerin büyük kısmının bildirim yaptığını, \%26.7'si ise üreticilerin çok azının bildirim yaptığını belirtmiştir (Çizelge 4). Komisyonculara, Hal Kayıt Sistemine ürün satışlarını bildiren üreticilerin bildirim miktarları sorulmuştur. Böylelikle, ürünlere göre sisteme kayıt olmayan ürün miktarlarının belirlenmesi amaçlanmıştır. Komisyonculara göre biber üreticisinin ürettiği ürünün \%90'ını; soğan üreticisinin \%82'sini; domates üreticisinin \%83.12'sini; patlıcan, karpuz, kavun üreticisinin $\% 80$ 'ini; patates üreticisinin $\% 78^{\prime}$ ini; şeftali üreticisinin \%76.06'sın1; hiyar üreticisinin \%75'ini; mandalina üreticisinin ise \%66.25'ini bildirdikleri saptanmıştır (Çizelge 5). Bu sonuçlar 1şığında, üreticilerin ürettikleri ürünlerin önemli bir kısmını Hal Kayıt Sistemine bildirdikleri anlaşılmıştır.

Çizelge 5. Komisyonculara göre Hal Kayıt Sistemine bildirilen ürünlerin oranı.

Table 5. Rate of products notified to the wholesale market registration system according to brokers' views.

\begin{tabular}{lcc}
\hline Bildirim Yapılan Ürünler & Sayı* & Yüzde (\%) \\
\hline Soğan & 5 & 82.00 \\
Patates & 15 & 78.00 \\
Mandalina & 16 & 66.25 \\
Seftali & 19 & 76.06 \\
Domates & 16 & 83.12 \\
Hiyar & 2 & 75.00 \\
Biber & 5 & 90.00 \\
Patlıcan & 1 & 80.00 \\
Karpuz & 1 & 80.00 \\
Kavun & 1 & 80.00 \\
Genel & 29 & 76.45 \\
\hline${ }^{*}$ Cevap veren komisyoncu sayısı. & &
\end{tabular}

Komisyonculara, üreticilerin Hal Kayıt Sistemine nasıl bildirim yaptıkları sorulduğunda ise \%36.7'si hale doğrudan başvuru ile \%30'u ise akıllı telefon uygulaması ile bildirim yaptıklarını söylemişlerdir (Çizelge 4).

Komisyonculara göre üreticilerin Hal Kayıt Sistemine bildirim yapmaktan kaçınmalarının nedenleri sorulduğunda ise \%56.7'si 'vergi ödemekten kaçınıyorlar' yanıtını vermişlerdir. Komisyoncuların \%63.3 gibi büyük bir çoğunluğu Hal Kayıt Sisteminin genel olarak iyi çalıştığını düşünmektedirler (Çizelge 4).

Çizelge 6. Komisyoncuların Hal Kayıt Sistemi konusunda gördükleri en önemli ve en önemsiz sorunlar.

Table 6. The most important and most insignificant problems in the wholesale market registration system according to brokers' views.

\begin{tabular}{|c|c|c|c|c|c|c|}
\hline Sorunlar & $\begin{array}{c}\text { En iyi } \\
\text { Frekans (B) }\end{array}$ & $\begin{array}{c}\text { En Kötü } \\
\text { Frekans }(\mathrm{W})\end{array}$ & B-W & $\operatorname{Sqrt}(\mathrm{B} / \mathrm{W})$ & $\begin{array}{c}\text { Standard } \\
\text { interval scale }\end{array}$ & $\begin{array}{c}\text { Ortalama } \\
(\mathrm{B}-\mathrm{W})\end{array}$ \\
\hline $\begin{array}{l}\text { Üreticilerin bu sistem hakkında bilgisinin olmaması ve } \\
\text { bilgi eksikliği }\end{array}$ & 26 & 1 & 25 & 5.10 & 100.00 & 0.81 \\
\hline $\begin{array}{l}\text { Denetim yetersizliği (üretilen önemli miktardaki ürünün } \\
\text { Hal Kayıt Sistemine bildirilmemesi) }\end{array}$ & 4 & 0 & 4 & - & - & 0.13 \\
\hline $\begin{array}{l}\text { Aracıların Hal Kayıt Sistemini bahane ederek üreticilere } \\
\text { verdikleri fiyatı düşürmeye çalışmaları ve sonrasında } \\
\text { ürünleri hale bildirmeyerek haksız rekabet oluşturmaları }\end{array}$ & 0 & 0 & 0 & - & - & 0.00 \\
\hline $\begin{array}{l}\text { Üreticilerin bilişim teknolojilerini (bilgisayar, akıllı } \\
\text { telefon uygulaması, vb.) kullanmadaki yetersizlikleri }\end{array}$ & 0 & 6 & -6 & - & - & -0.19 \\
\hline $\begin{array}{l}\text { Hükümetin haller için uygulamaya çalıştığı mevzuatta } \\
\text { sürekli değişim yaşanması }\end{array}$ & 0 & 8 & -8 & - & - & -0.26 \\
\hline $\begin{array}{l}\text { Hal Kayıt Sisteminin taraflar açısından kullanımının kolay } \\
\text { (pratik)olmaması }\end{array}$ & 0 & 11 & -11 & - & - & -0.35 \\
\hline Sistemin yavaş çalışması & 0 & 4 & -4 & - & - & -0.13 \\
\hline
\end{tabular}

$\mathrm{Bu}$ çalışmada komisyoncuların Hal Kayıt Sistemi ile ilgili gördükleri en önemli ve en önemsiz sorunlar da ortaya konulmuştur. Bu amaçla En İyi-En Kötü Analizi (Best-Worst) yapılmıştır. Ortalama B-W değerine bakılarak komisyoncuların geneli itibariyle bir değerlendirme yapıldı̆̆ında, komisyoncuların Hal Kayıt Sistemi hakkında gördükleri en önemli sorunun "üreticilerin bu sistem hakkında bilgisinin olmaması ve bilgi eksikliği" olduğu belirlenmiştir (Çizelge 6). 0.81 ile en büyük pozitif ortalama B-W değerine sahip olan bu sorun bir anlamda Hal Kayit Sisteminin temelinde bulunan en önemli sorunun ne olduğunu ortaya koymaktadır. Komisyonculara göre Hal Kayıt Sistemine ilişkin görülen en önemli ikinci sorun ise $0.13 \mathrm{~B}-\mathrm{W}$ değeri ile "denetim yetersizliği”" olarak saptanmıştır. Komisyoncular, üretilen önemli miktardaki ürünün Hal Kayıt Sistemine bildirilmediği görüşündedir.

En İyi-En Kötü analizi ile komisyoncuların Hal Kayıt Sistemi hakkında gördükleri en önemsiz sorunlara yönelik bir değerlendirme de yapılmıştır. Gerçekleştirilen analize göre (-) 0.35 ile en küçük negatif ortalama B-W değerine sahip olan Hal Kayıt Sisteminin taraflar açısından kullanımının kolay (pratik) olmaması komisyoncuların söz konusu kayıt sistemi hakkındaki gördükleri en önemsiz olan sorundur. Komisyoncular açısından en önemsiz düzeyde görülen ikinci ve üçüncü sorunlar ise sırasıyla; "hükümetin haller için uygulamaya çalıştığı mevzuatta sürekli değişim yaşanması" ve "üreticilerin bilişim teknolojilerini (bilgisayar, akıllı telefon uygulamas1, vb.) kullanmadaki yetersizlikleri” olarak belirlenmiştir (Çizelge 6).

Karar alıcı olarak devlet, Hal Kayıt Sistemi ile sebze ve meyvelerde kayıt dışı işlemleri önlemeyi hedeflemişti. Bu amaçla komisyonculara 5957 say1lı yasa kapsamında hal kanununda yer verilen Hal Kayıt Sistemi ile ilgili düzenlemenin kayıt dışı işlemleri önlemede etkisi olup olmadığı sorulmuştur. Alınan cevaplar, görüşülen komisyoncuların bu konuda farklı görüşlerde olduğunu göstermektedir. Nitekim, komisyoncuların \%36.7'si Hal Kayıt Sisteminin kayıt dışılığı önlemede etkisinin olmadığını düşünürken, \%30'u oldukça etkili olduğunu, \% 30’u da bu konuda kararsız kaldıklarını belirtmişlerdir (Çizelge 7).

Görüşme yapılan komisyonculara, toptancı hallerinde yapılan denetimlerin yeterli olup olmadığına ilişkin bir soru da yöneltilmiştir. Komisyoncuların \%40’1 bu konuda kararsız kalırken, önem derecesine göre değişmekle birlikte \%30'u yetersiz olduğunu düşünmektedir (Çizelge 7). 
Çizelge 7. Komisyoncuların kayıt dışılık ve toptancı hallerinin yönetimi hakkındaki görüşleri.

Table 7. Brokers' views on unregistered transactions and management of wholesale markets.

\begin{tabular}{llc}
\hline Yöneltilen Sorular & Seçenekler & Yüzde (\%) \\
\hline Hal Kayıt Sisteminin kayıt & Hiç etkili olmadı & 36.7 \\
dışıllğı etkileme düzeyi & Biraz etkili oldu & 3.3 \\
& Orta (kararsız) & 30.0 \\
& Oldukça etkili oldu & 30.0 \\
& Kesinlikle çok etkili oldu & - \\
\hline Toptancı hallerinin & Çok yetersiz & 3.3 \\
denetiminin yeterli olma & Yetersiz & 26.7 \\
durumu & Ne yeterli ne yetersiz & 40.0 \\
& Yeterli & 23.3 \\
& Çok yeterli & 6.7 \\
\hline Komisyonculara göre & Belediyeler & 36.7 \\
toptancı hallerini & Özel sektör & 6.7 \\
yönetmesi gereken kuruluş & Her ikisi de olabilir & 56.7 \\
\hline
\end{tabular}

$\mathrm{Bu}$ çalışma kapsamında, komisyonculardan toptancı hallerinin yönetiminin kimler tarafindan üstlenilmesi gerektiği konusunda belediyeler ve özel sektör açısından bir değerlendirme yapmaları istenilmiştir. Komisyoncuların yaklaşı \%57'si hal yönetiminin hem belediyeler hem de özel sektör tarafından yapılabileceği görüşündedir. Toptanc1 hallerinin sadece belediyeler tarafindan idare edilmesi gerektiğini düşünen komisyoncuların oranı ise \%36.7'dir (Çizelge 7).

\section{Sonuç ve Öneriler}

$\mathrm{Bu}$ çalışma ile 11.03.2010 tarih ve 5957 sayılı kanunla hayata geçirilen Hal Kayıt Sisteminin kayıt dışıllğı önlemek adına işlevsel olarak etkin çalışıp çalışmadığı sorusuna yanıt aranmıştır. $\mathrm{Bu}$ sorunun yanıtı sistemin en önemli kullanıcılarından birisi olan komisyoncular ile yapılan yüz yüze görüşmeler ile neticesinde verilmeye çalış1lmıştır.

Komisyoncuların görüşlerine göre Hal Kayıt Sisteminde görülen en önemli sorunlardan birisi üretilen ürünlerin önemli bir kısmının sisteme kayıt olmadan pazara arz edilmesidir. Bunun da en önemli nedeni olarak Hal Kayıt Sistemi hakkında üreticilerin bilgi eksikliği gösterilmektedir. Sistem ilk kurulduğunda var olan bu sorun halen giderilememiş̧tir. Kırsalda birçok üretici Hal Kayıt Sisteminin ne olduğunu ve nasıl işlediğini ya bilmemekte ya da eksik bir bilgiye sahiptir. Devletin üretilen ürünlerin sisteme girip girmediği konusundaki denetim mekanizması ise etkin çalışmamaktadır. Zaten önemli bir miktarda tarımsal ürünün üretildiği Türkiye'de bu ürünlerin sisteme kaydı için denetimin nasıl yapıldığına ilişkin somut bir bilgiye de rastlanmamıştır. Bu bulgular 1şığında kayıt dış1lı̆̆ önlemek amaciyla kurulan Hal Kayıt Sisteminin etkin çalışmadığını söylemek mümkündür.

Tarımsal üreticiler, Hal Kayıt Sistemine bildirim yapanlar içinde önemli paya sahiptir. Bu nedenle sistemdeki kayıt dış1lı̆̆ önlemek amaciyla özellikle de üreticilere yönelik bilgilendirme ve sistemin nasıl kullanılacağına ilişkin eğitim çalışmaları önem taşımaktadır. Eğitim çalışmalarında, üreticilerin ücretsiz olarak indirip kullanabileceği, Hal Kayıt Sisteminin işleyişine yönelik akıllı telefon uygulamaları ile üreticilere görsel olarak sistemin işleyişi öğretilebilir. Ayrıca; Facebook ve Instagram gibi sosyal medya platformlarında bu uygulamaların tanıtımları yapılarak üreticilerin dikkati çekilebilir. Bunun yanında, sisteme kayıt olmak koşuluyla bazı avantajlar sunularak üreticilerin sisteme ürün satışlarını bildirmeleri teşvik edilebilir.
Son zamanlarda, tarımsal ürünlerdeki fiyat artışları çok konuşulmaktadır. Fiyat artışlarını kontrol altına almak ise önemli ölçüde arzın kontrol edilmesine bağlıdır. Bu da mümkün olduğunca kayıt dişıllğın önüne geçilmesi ile mümkün olabilecektir. Şüphesiz ki Hal Kayılt Sisteminin önemli kullanıcılarından birisi de komisyonculardır. Ancak, bu sisteme bildirim yapan sadece komisyoncular değildir. Komisyoncular dışında tüccarlar, pazarcılar, manavlar, ihracatçılar ve marketler gibi bildirim yapan çok sayıda aktör vardır. Dolayısıyla sadece komisyoncu odaklı bir denetim mekanizması sistemin etkin bir şekilde çalışmasını sağlamayacaktır. Bunun yerine, üreticiler de dahil olmak üzere sistemin içerisinde yer alan tüm aktörlerin denetlendiği bir sistemin planlanması üzerinde çalışılması daha etkin bir sonuç alınmasına imkan verecektir.

\section{Kaynaklar}

Adanacioğlu H, Yercan M (2012) Yeni Hal Kanununun Tarım Kesimine Olan Muhtemel Etkilerinin Değerlendirilmesi. 10. Ulusal Tarım Ekonomisi Kongresi, s. 844-845.

Apalı A, Bozcu M (2018) Hal Komisyonculuğunda Belge Düzeni Açısından Vergi Usul Kanununun Uygulanmasında Ortaya Çıkan Farklılıkların Araştırılması: Antalya Toptancı Hali Örneği. Diyalektolog Ulusal Sosyal Bilimler Dergisi 19: 467-478.

Aydın Can B, Engindeniz S (2018) Tarım Ürünlerinin Pazarlanmasında Toptancı Hallerinin Rolü ve Önemi: Kocaeli Merkez İlçe Toptancı Hali Örneği. Selçuk Tarım ve Gıda Bilimleri Dergisi 32(3): 266273.

Aysoy C, Kırlı DH, Tümen S (2015) Taze Meyve-Sebze Tedarik Zincirindeki Engelleri Azaltıcı Tedbirlerin Fiyatlar Üzerindeki Etkisi. TCMB Ekonomi Notları 3: 1-12.

Canik F, Alparslan Y (2010) Türkiye'de Yaş Meyve ve Sebze Pazarlaması ve Toptancı Halleri. Tarımsal Ekonomi ve Politika Geliştirme Enstitüsü 11:2-8.

Çiçek A, Erkan O (1996) Tarım Ekonomisinde Araştırma ve Örnekleme Yöntemleri, Gaziosmanpaşa Üniversitesi Ziraat Fakültesi Yayınları No: 12, Ders notları serisi: 6 .

Coşkun H (2014) Aydın İlinde Yaş Sebze ve Meyve Toptancı Hallerinin İncelenmesi. Yüksek Lisans Tezi, Adnan Menderes Üniversitesi Fen Bilimleri Enstitüsü, Aydın.

Coşkun MH, Tunalığlu R (2015) Aydın İlinde Yaș Sebze ve Meyve Toptanc1 Hallerinin İncelenmesi. Adnan Menderes Üniversitesi Ziraat Fakültesi Dergisi 12(2): 83-92.

Demirbaş N (2001) Türkiye'de Toptancı Halleri ile İlgili Yasal Düzenlemelerin Meyve-Sebze Üretim ve Pazarlama Politikalarının Başarısı Üzerine Etkileri: İzmir İli Örneği. Türkiye Ziraat Odaları Birliği, s. 1-2.

Emeksiz F, Albayrak M, Güneş E, Özçelik A, Özer OO, Taşdan K (2014) Türkiye'de Tarımsal Ürünlerin Pazarlama Kanalları ve Araçlarının Değerlendirilmesi. Türkiye Ziraat Mühendisleri Odası Teknik Kongresi, Bildiriler (II), 1155-1172.

Giray FH (1998) Yeni Hal Yasası Gerçekten Yeni Bir Yasa mı?. TürkKooperatif Ekin Dergisi s. 52-56.

Gözener B, Sayılı M (2011) Tokat İli Merkez İlçede Toptancı Halindeki Komisyoncuların Yeni Hal Yasası Hakkındaki Görüşleri. Gaziosmanpaşa Üniversitesi Ziraat Fakültesi Dergisi 28(2): 227 235.

Hadimli H, Bulut İ (2004) Antalya'da Sebze-Meyve Ticareti ve Antalya Toptancı Hali'ne Coğrafi Bir Yaklaşım. Doğu Coğrafya Dergisi 11: 261-282.

İzmir Valiliği (2017) www.izmir.gov.tr. Erişim 19 Mayıs 2017.

Ölmez S, Demirörs MO (2015) Yeni Hal Yasası Üzerine Bir Derleme. Türk Bilimsel Derlemeler Dergisi 8(2): 59-65 
Resmi Gazete (2010) Sebze ve Meyveler ile Yeterli Arz ve Talep Derinliği Bulunan Diğer Malların Ticaretinin Düzenlenmesi Hakkında Kanun. 26.03.2010 Tarihli Resmi Gazete, Kanun No. 5957, Sayı: 27533.

Resmi Gazete (2012) Sebze ve Meyve Ticareti Ve Toptancı Halleri Hakkında Yönetmelik. Resmî Gazete Tarihi: 07.07.2012, Resmî Gazete Sayısı: 28346.

Sayılı M, Civelek O (2012) Tokat İli Merkez İlçede Yaș Sebze ve Meyve Toptancı Halinin Yapısı, Sorunları ve Çözüm Önerileri.
Tarımsal Ekonomi ve Politika Geliştirme Enstitüsü (TEBGE), Yayın No:203.

Sayın C, Mencet MN (2007) Hal Yasası'nın Yaş Meyve ve Sebze Pazarlamasındaki Etkinliğinin Tartışılması. GAP V. Tarım Kongresi, 17-19 Ekim: 1.

Yılmaz S, Yılmaz İ (2002) Türkiye Yaş Meyve ve Sebze Pazarlamasinda Toptancı Hal Sisteminin Değerlendirilmesi: Antalya Büyükşehir Belediyesi Toptancı Hali Örneği. Türkiye V. Tarım Ekonomisi Kongresi, s. 292-299. 